ISSN: 2277-3754

ISO 9001:2008 Certified

International Journal of Engineering and Innovative Technology (IJEIT)

Volume 10, Issue 3, September 2020

\title{
Designing and analysis of lifting eye bolt for various geometry
}

Abdulla Adhil C, Akhil Muhammed, Jithin P, Navag Pradeep, Jibi.R

Department of Mechanical Engineering, AWH Engineering College Calicut Kerala India

Abstract - This paper aims to designing and analysis of various geometry eye bolt hooks used In the industries. Aim of this work is to study stress and deformation induced in a eye bolt hook having various cross section. Various cross sections selected are circular, rectangular and Trapezoidal modeling of software is done by AUTOCAD Software. Theoretical analysis and FEA analysis carried out to compare the result. and also, the eye bolt with minimum stress is analyzed.

\section{Keywords: FEA, AUTOCAD, EYE BOLT.}

\section{INTRODUCTION}

The eye bolt hook is a very critical feature used to lift the load using a chain or seam. The eyebolt hook is a highly responsible component, which is normally used for industrial purposes. The protection of the loaded crane has a great role to play in these hooks. The pace at which these hooks are forged is growing with more and more industrialization. This study involves stress and deformation caused by various cross-sectors in the eyebolt hook for a specific loaded state. The eyebolts of the machinery are completely fastened with a collar that can be used with angulate loads up to 45 degrees. For angular loads, no shoulder bolts should be used. Heavy forged eyebolts can be designed with the integral shoulder with a continuous eye, enabling their use in heavy off axis loads. Sometimes eyebolts are placed in masonry so that they usually provide variations of their very own anchor bolt. Most of these screw into a shield anchor. Certain lightweight shapes are not screwed, but only rely on the pull on the anchor itself.

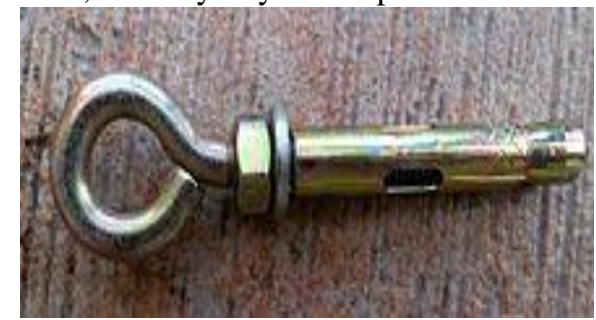

Fig.1.Eye bolt with integral wall anchor

\section{LITERATURE REVIEW}

Present competitive market demands defect free product with lowest possible prize and prompt delivery. The stress that is caused must be investigated in order to mitigate the failure of Crane. There are two main methods to classify an eyebolt.

Manuscript received: 27 August 2020

Manuscript received in revised form: 24 September 2020

Manuscript accepted: 10 October 2020

Manuscript Available online: 15 October 2020
- Maximum capacity for loading - The maximum load that a bolt can bear.

- Length shank-The shank's diameter is equal to the thread length for threaded eyebolts.

- Length of thread $\bullet$

- Diameter of the eye (ID) •

- Diameter or thickness of the eye segment

- Weight gross

\section{METHODOLOGY}

To ensure that the project is fluent and that the outcome is anticipated, methods are the most important element to consider. This can also be described as a frameworks methodology where it involves job elements focused on the project goals and scope. A successful system work can easily obtain an overview of the project. This includes 3D modeling and use of the flow process map in a literature review.

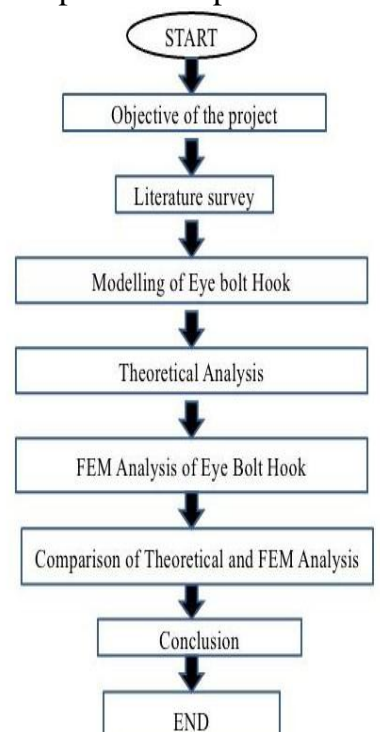

Fig.2. Methodology

\section{IMPLEMENTATION WORK}

A. Eye bolt section of circular cross section

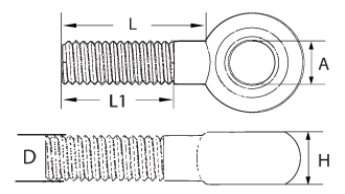

Fig.3.Component Drawing

\section{B. MODELLING OF EYE BOLT}

Circular rectangle and trapezium are the chosen sections. 
ISSN: 2277-3754

ISO 9001:2008 Certified

International Journal of Engineering and Innovative Technology (IJEIT)

Volume 10, Issue 3, September 2020

- Area tends to be stable as three different parts of the dimensions change.

High strength, low alloy steel is the material chosen.

The below are characteristics of high strength low alloy steel.

\begin{tabular}{|l|l|}
\multicolumn{2}{c}{ Table 1.Material Composition } \\
\hline Density & $\mathbf{7 8 5 0 \mathrm { kg } / \mathrm { m } 3}$ \\
\hline Tensile yield strength & $250 \mathrm{Mpa}$ \\
\hline Poisson ratio & 0.3 \\
\hline Tensile ultimate strength & $460 \mathrm{Mpa}$ \\
\hline
\end{tabular}

\section{LIFTING EYE BOLT - CIRCULAR SECTION}
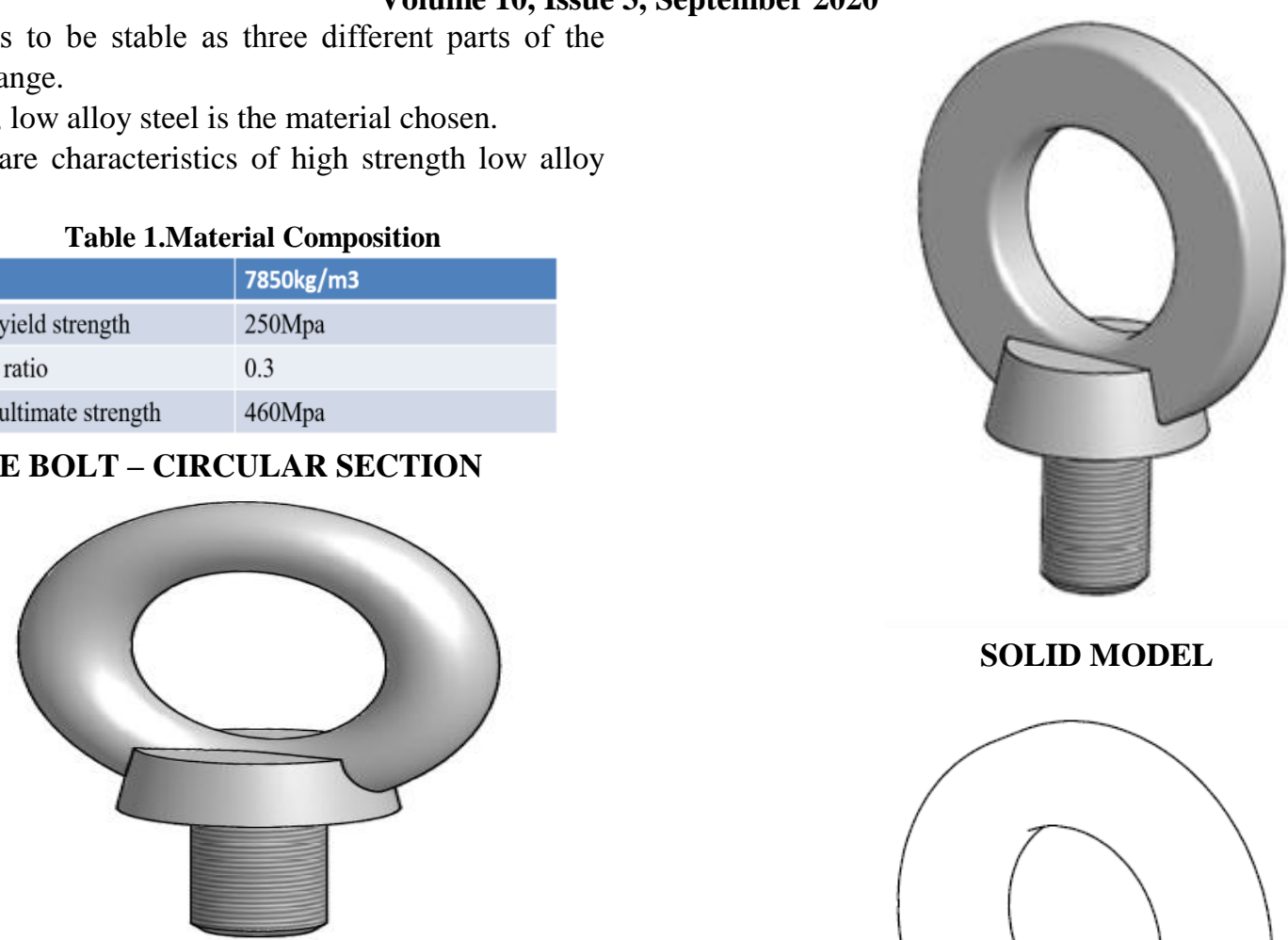

SOLID MODEL

SOLID MODEL
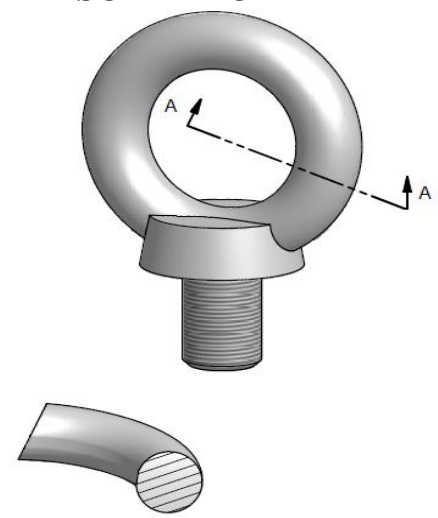

SECTION A-A
SCALE $1: 1$

SECTIONAL VIEW

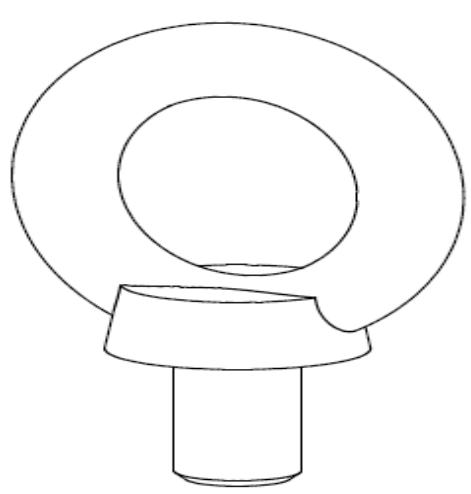

WIRE FRAME MODEL

Fig.4. Modeling of circular section

LIFTING EYE BOLT - RECTANGULAR SECTION

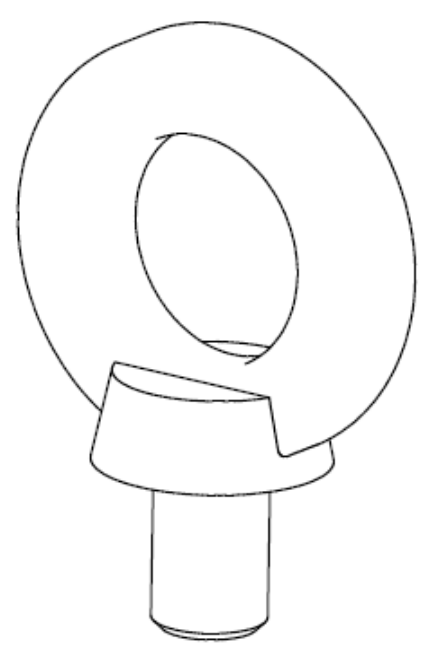

WIRE FRAME MODEL
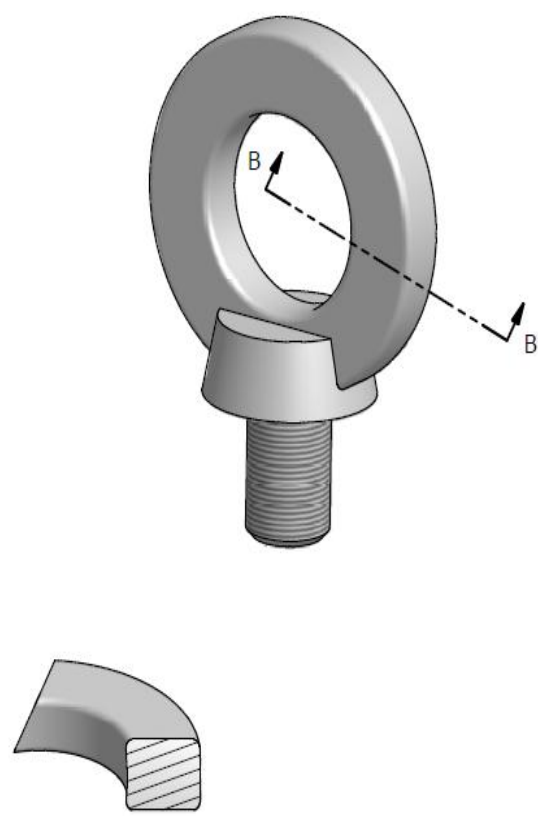

SECTIONALVIEW

Fig.5.Modelling of rectangular section LIFTING EYE BOLT-TRAPEZIODAL SECTION 
ISSN: 2277-3754

ISO 9001:2008 Certified

International Journal of Engineering and Innovative Technology (IJEIT)

Volume 10, Issue 3, September 2020

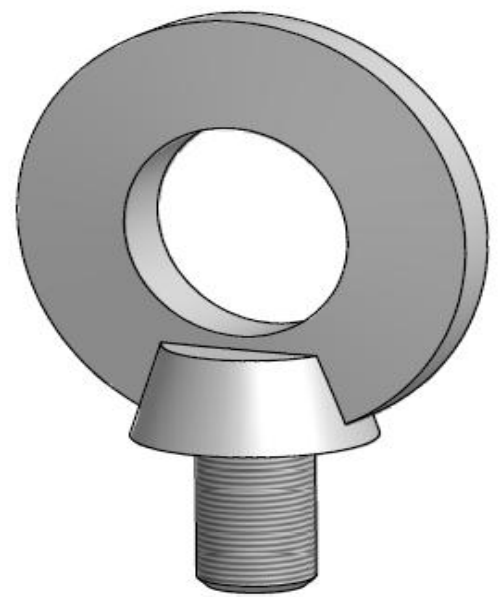

SOLID MODEL

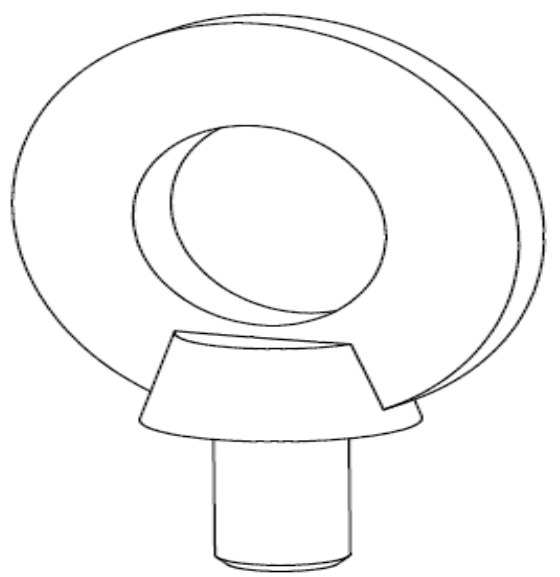

WIRE FRAME MODEL

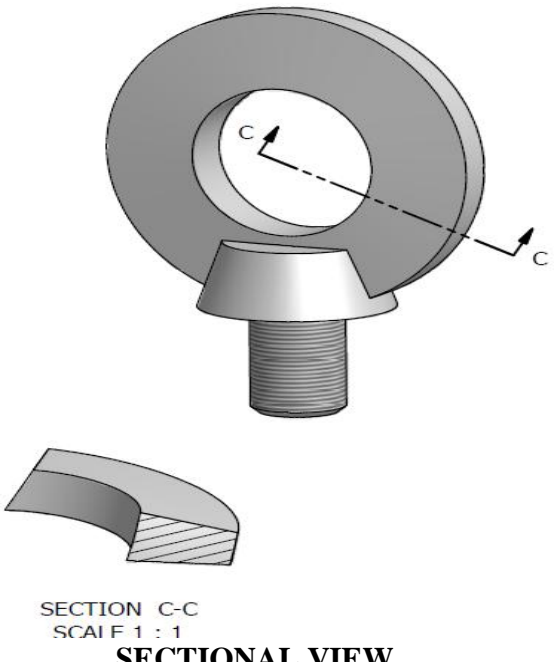

SECTIONAL VIEW

Fig.6.Modelling of trapezoidal section

\section{METHODS FOR MEASURMENT OF STRESS ON CRANE HOOK}

The principal measurement and analysis procedure for finding the stress in crane hook are:-

(i) Theoretical Analysis

(ii) FEM Analysis

(i) THEORETICAL ANALYSIS
When a part curves as with the eyebolt for various cross sections, the mathematical stress analysis is pronounced, the beam flexure formula is used. The eyebolt is subject to the following curved bar:

Against strain direct

Towards tension bending

There is no linear stress allocation in the curved beam. The neutral axis in the curved beam is not aligned with the central or geometric axis, but moves from a distance towards the centre of the curvature. This is because the bending stress is not linearly distributed. Resultant stress in an eye bolt = Direct stress+ Bending stress

$$
\sigma=\frac{F}{A}+\frac{M \times y}{I}
$$

Where,

$\mathrm{F}=$ Load acting on eye bolt

$A=$ Area of cross section

$\mathrm{M}=$ maximum bending moment.

$\mathrm{Y}=$ Distance between centroidal axis to neutral axis

I=Moment of inertia for different cross section

\section{A. STRESS CALCULATION FOR CIRCULAR CROSS SECTION}

Length between centroidal axis to neutral axis (e) centroidal and neutral axis of circular section.

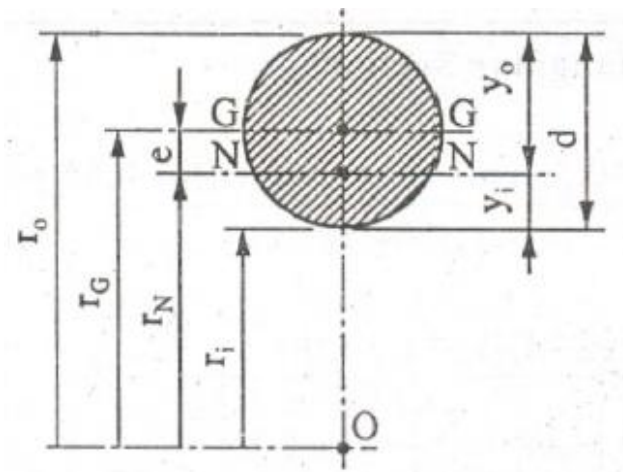

Fig.7. Length between centroidal axis to neutral axis (e) centroidal and neutral axis of circular section

$$
\begin{aligned}
& r_{\mathrm{G}}=\mathrm{r}_{\mathrm{i}}+\frac{\mathrm{d}}{2} \\
& \mathrm{r}_{\mathrm{N}}=\frac{\left(\sqrt{\mathrm{r}_{\mathrm{o}}}+\sqrt{\mathrm{r}_{\mathrm{i}}}\right)^{2}}{4}
\end{aligned}
$$

Distance between centroidal axis to neutral axis $(e)=r_{G}-r_{N}$ $\mathrm{r}_{\mathrm{G}}=$ Radius of curvature of centroidal axis. $\mathrm{r}_{\mathrm{N}}=$ Radius of curvature of neutral axis. $\mathrm{r}_{\mathrm{G}}=\mathrm{r}_{\mathrm{i}}+\mathrm{d} / 2$

Where $r_{i}=$ Radius of curvature of inside fiber $=25 \mathrm{~mm}$. $\mathrm{d}=$ diameter of circular cross section.

$$
\mathrm{r}_{\mathrm{G}}=\mathrm{r}_{\mathrm{i}}+\mathrm{d} / 2=25+20 / 2=35 \mathrm{~mm} \text {. }
$$$$
\mathrm{r}_{\mathrm{N}}=\left(\sqrt{ } \mathrm{r}_{\mathrm{o}+} \sqrt{ } \mathrm{r}_{\mathrm{i}}\right)^{2} \div 4
$$

Where $r_{o}=$ Radius of curvature of outer fiber $=45 \mathrm{~mm}$ 
ISSN: 2277-3754

ISO 9001:2008 Certified

International Journal of Engineering and Innovative Technology (IJEIT)

$r_{N}=\left(\sqrt{ } 45_{+} \sqrt{ } 25\right)^{2} \div 34.27 \mathrm{~mm}$

Volume 10, Issue 3, September 2020

Distance between centroidal axis to neutral axis (e)

$$
=r_{G}-r_{N}
$$

$$
=35 \mathrm{~mm}-34.27=0.73 \mathrm{~mm}
$$

Moment about centroidal axis.

$$
\begin{aligned}
& =F x l=981 \times 10=9810 \mathrm{Nmm} \\
& \mathrm{I}=\pi \mathrm{D}^{4} / 64 \\
& \mathrm{I}=\pi 20^{4} / 64=7850 \mathrm{~mm}^{4}
\end{aligned}
$$

Resultant stress in an eye bolt.

$$
=\text { Direct stress }+ \text { Bending stress }
$$

$$
\sigma=\frac{F}{A}+\frac{M \times y}{I}
$$

$=981 / 314+((9810 \times 0.73) / 7850)=\underline{4.036 \mathrm{~N} / \mathrm{mm}^{2}}$

\section{B. STRESS CALCULATION FOR RECTANGULAR CROSS SECTION}

Distance between centroidal axis to neutral axis (e) Centroidal and neutral axis of Rectangular section.

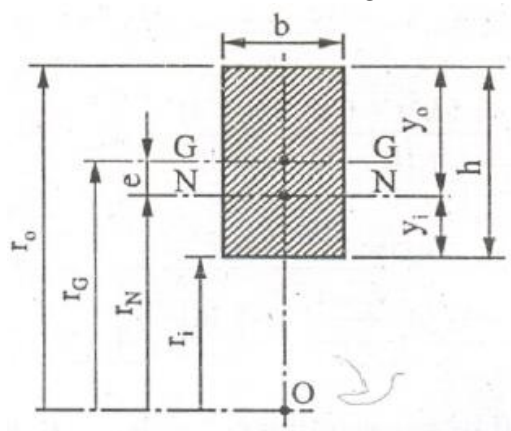

Fig.8. Length between centroidal axis to neutral axis (e)

Centroidal and neutral axis of Rectangular section.

$$
\begin{aligned}
& r_{G}=r_{i}+\frac{h}{2} \\
& r_{N}=\frac{h}{\ln \left(\frac{r_{0}}{r_{i}}\right)}
\end{aligned}
$$

Distance between centroidal axis to neutral axis $(e)=r_{G}-r_{N}$ $r_{G}=$ Radius of curvature of centroidal axis.

$\mathrm{r}_{\mathrm{N}}=$ Radius of curvature of neutral axis.

$r_{\mathrm{G}}=\mathrm{r}_{\mathrm{i}}+\mathrm{h} / 2$

Where $r_{i}=$ Radius of curvature of inside fiber $=25 \mathrm{~mm}$. $\mathrm{h}=$ height of rectangular cross section. $\mathrm{r}_{\mathrm{G}}=\mathrm{r}_{\mathrm{i}}+\mathrm{h} / 2=25+21 / 2=35.5 \mathrm{~mm}$.

$\mathrm{r}_{\mathrm{N}}=\mathrm{h} / \ln \left(\mathrm{r}_{\mathrm{o}} / \mathrm{r}_{\mathrm{i}}\right)$

$$
\mathrm{r}_{\mathrm{N}}=21 / \ln (46 / 25)=34.48 \mathrm{~mm}
$$

Where $r_{o}=$ Radius of curvature of outer fiber $=46 \mathrm{~mm}$ Distance between centroidal axis to neutral axis $(e)=r_{G}-r_{N}$ $=35.5-34.48=1.02 \mathrm{~mm}$

Moment about centroidal axis.

$$
=\mathrm{Fxl}=981 \times 10.5=10300.5 \mathrm{Nmm}
$$

\section{$\mathrm{I}=\mathrm{bh}^{3} / 12$}

$\mathrm{I}=15 \times 21^{3} / 12=11576.25 \mathrm{~mm}^{4}$

Resultant stress in an eye bolt.

$=$ Direct stress + Bending stress

$$
\sigma=\frac{F}{A}+\frac{M \times y}{I}
$$

$=981 / 314+\left((10300 \times 1.02) / 11576.25=\underline{4.031 \mathrm{~N} / \mathrm{mm}^{2}}\right.$

\section{STRESS CALCULATION FOR TRAPEZOIDAL CROSS SECTION}

Distance between centroidal axis to neutral axis (e) Centroidal and neutral axis of Rectangular section.

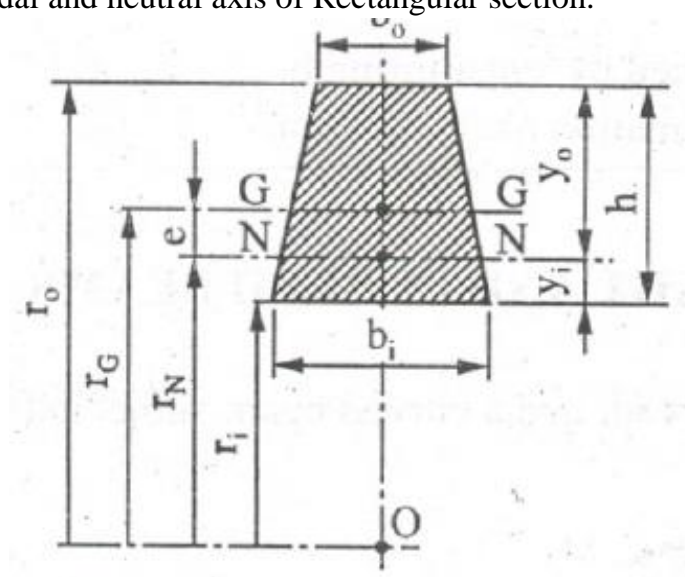

Fig.9. Length between centroidal axis to neutral axis (e) Centroidal and neutral axis of Rectangular section

$$
\begin{aligned}
& r_{G}=r_{i}+\frac{h}{3}\left[\frac{b_{i}+2 b_{0}}{b_{i}+b_{o}}\right] \\
& r_{N}=\frac{A}{\left[\frac{\left(b_{i} r_{o}-b_{o} r_{i}\right)}{h}\right] \ln \left(\frac{r_{0}}{r_{i}}\right)-\left(b_{i}-b_{o}\right)}
\end{aligned}
$$

Distance between centroidal axis to neutral axis $(e)=r_{G}-r_{N}$ $\mathrm{r}_{\mathrm{G}}=$ Radius of curvature of centroidal axis. $\mathrm{r}_{\mathrm{N}}=$ Radius of curvature of neutral axis.

$$
r_{G}=r_{i}+\frac{h}{3}\left[\frac{b_{i}+2 b_{o}}{b_{i}+b_{o}}\right]
$$

Where $r_{i}=$ Radius of curvature of inside fiber $=25 \mathrm{~mm}$. $\mathrm{h}=$ height of trapezoidal cross section. $=25.12 \mathrm{~mm}$

Length of bases $=15$ and $10 \mathrm{~mm} \mathrm{rG}=42.584 \mathrm{~mm}$

$$
r_{N}=\frac{A}{\left[\frac{\left(b_{i} r_{0}-b_{0} r_{i}\right)}{h}\right] \ln \left(\frac{r_{0}}{r_{i}}\right)-\left(b_{i}-b_{0}\right)}
$$

Where $r_{o}=$ Radius of curvature of outer fiber $=46 \mathrm{~mm}$ $r_{i}=$ Radius of curvature of inside fiber $=50.12 \mathrm{~mm}$ $\mathrm{r} \mathrm{n}=41.47 \mathrm{~mm}$

Distance between centroidal axis to neutral axis $(\mathrm{e})=\mathrm{r}_{\mathrm{G}}-\mathrm{r}_{\mathrm{N}}$

$=42.58-41.47=1.114 \mathrm{~mm}$ 
ISSN: 2277-3754

ISO 9001:2008 Certified

International Journal of Engineering and Innovative Technology (IJEIT)

Volume 10, Issue 3, September 2020

Moment about centroidal axis

$=\mathrm{Fxl}=981 \times 12.56=12321.365 \mathrm{Nmm}$

$$
\begin{aligned}
& I=h^{3}(3 a+b) / 12 \\
& I=25.12^{3}
\end{aligned}
$$

$(3 \times 15+10) / 12=72650 \mathrm{~mm}^{4}$

Resultant stress in a eye bolt $=$ Direct stress + Bending stress

$$
\sigma=\frac{F}{A}+\frac{M \times y}{I}
$$

$=981 / 314+((12321.3 \times 1.11) / 72650)=3.308 \mathrm{~N} / \mathrm{mm}^{2}$

\section{FEM-ANALYSIS FOR STRESS CALCULATION}

$>$ Software: Auto Desk Inventor FEA package

- FEA Analysis of eye bolt having Circular Cross Section

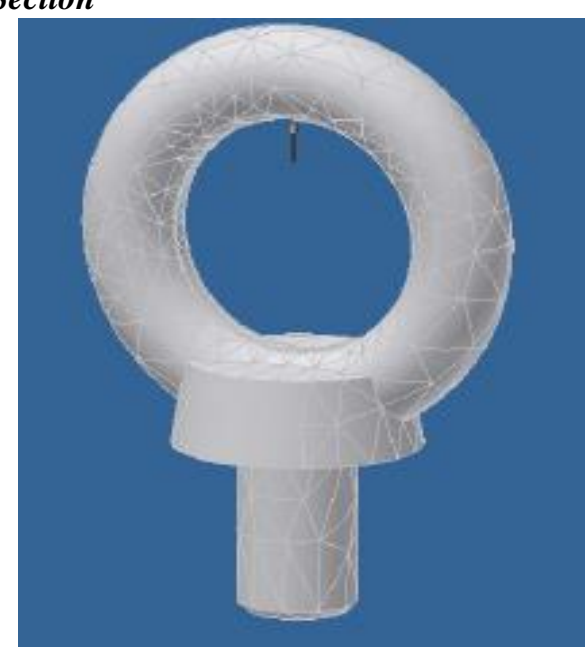

MESH MODEL

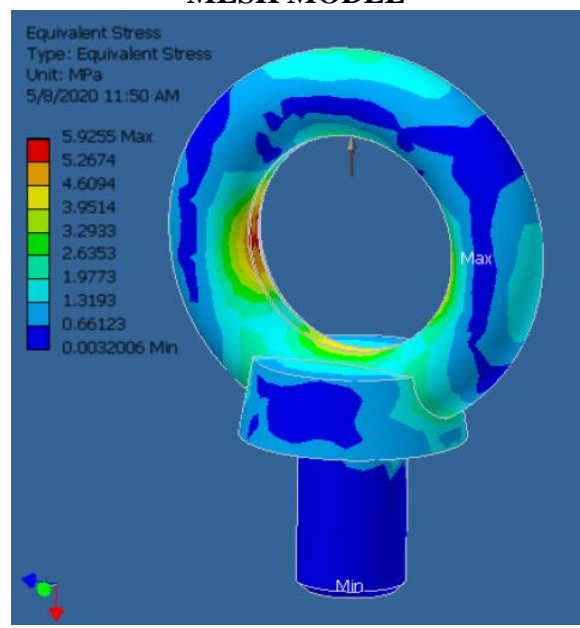

EQUAVALENT STRESS

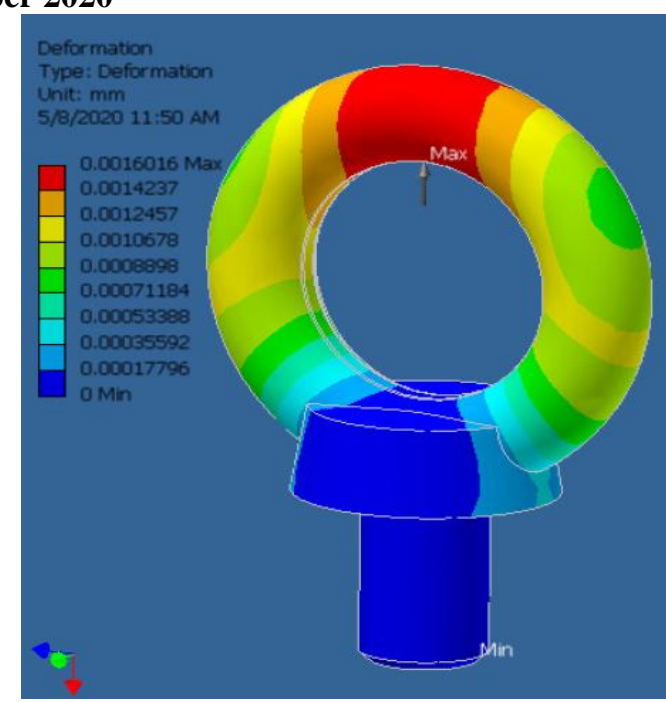

\section{DEFORMATION}

Fig.10.FEA Analysis of Eye Bolt Having Circular Cross Section

Table 2.Induced Stress and Deformation Eye Bolt Hook Table 2.Induced Stress and Cross Section
Circular Cof

\begin{tabular}{|c|c|c|}
\hline & Maximum Value & Minimum Value \\
\hline Equivalent Stress & $5.9255 \mathrm{~N} / \mathrm{mm}^{2}$ & $0.0032006 \mathrm{~N}^{2} \mathrm{~mm}^{2}$ \\
\hline Deformation & $0.0016016 \mathrm{~mm}$ & \\
\hline
\end{tabular}

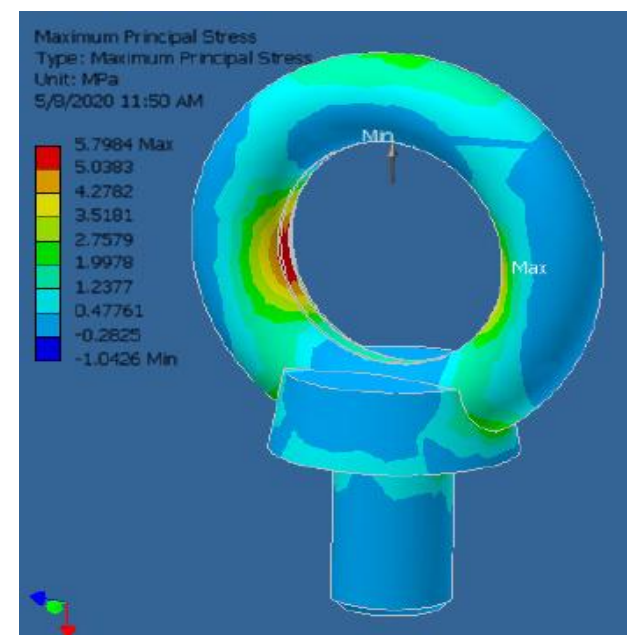

MAXIMUM PRINCIPAL STRESS

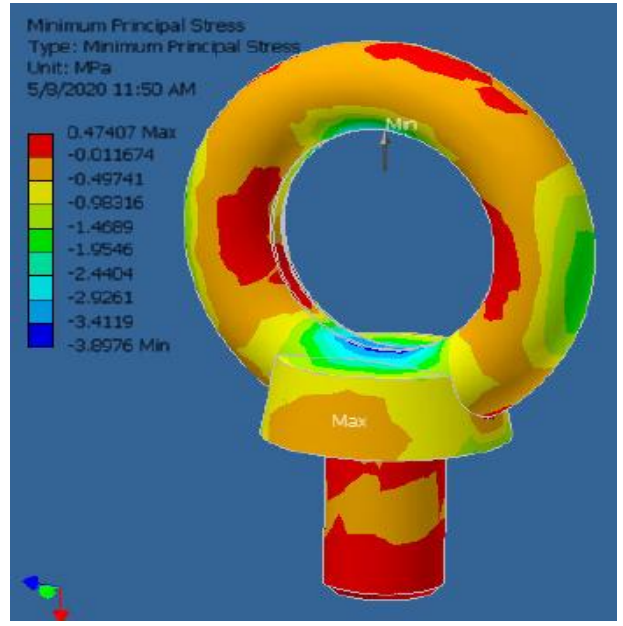

MINIMUM PRINCIPAL STRESS 


\section{|VEEIT}

ISSN: 2277-3754

ISO 9001:2008 Certified

International Journal of Engineering and Innovative Technology (IJEIT)

Volume 10, Issue 3, September 2020

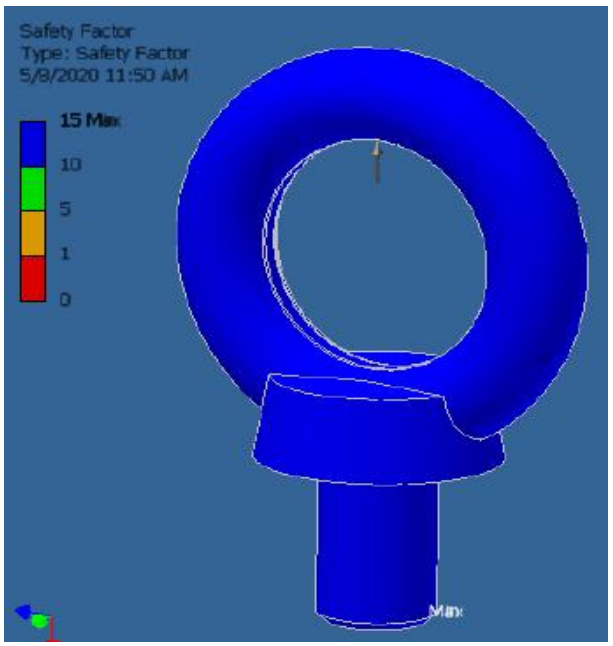

SAFETY FACTOR

Fig.11.Maximum Principle Stress, Minimum Principle

Stress and Safety factor of Circular cross section

E. FEM Analysis of eye bolt having Rectangular Cross Section

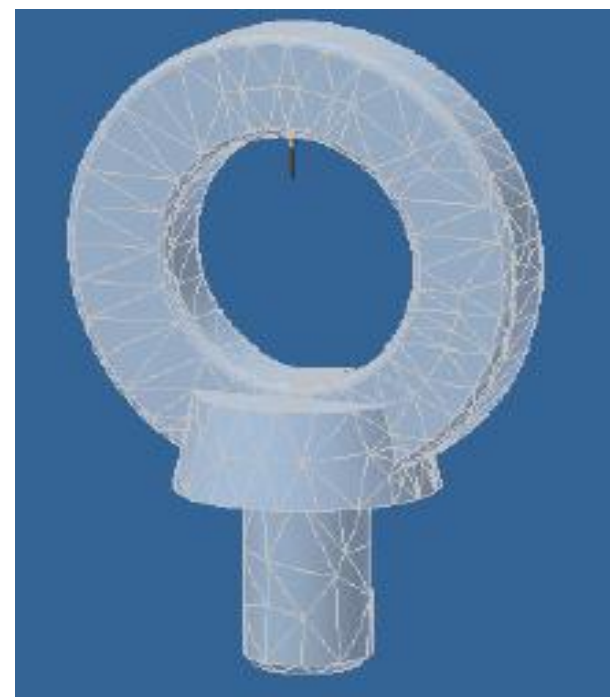

MESH MODEL

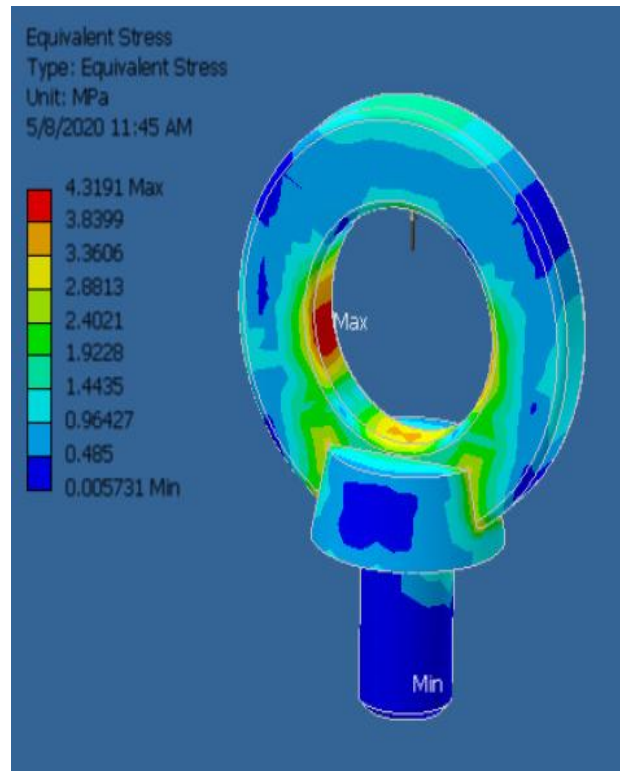

EQUAVALENT STRESS

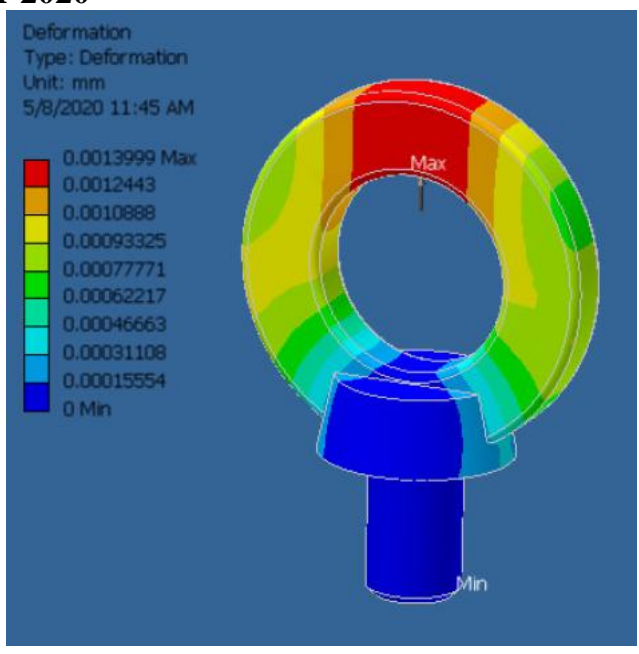

\section{DEFORMATION}

Fig.12. FEA analysis of Eye Bolt Having Rectangular Cross Section

Table 3. Induced Stress and Deformation Eye Bolt Hook Rectangular Cross Section

\begin{tabular}{|c|c|c|}
\hline & Naximum Value & Vinimum Value \\
\hline Equivalent Stress & $4.3191 \mathrm{~N}_{\mathrm{mm}} \mathrm{m}^{2}$ & $0.005731 \mathrm{Nmm}^{2}$ \\
\hline Deformation & $0.0013999 \mathrm{~mm}$ & \\
\hline
\end{tabular}

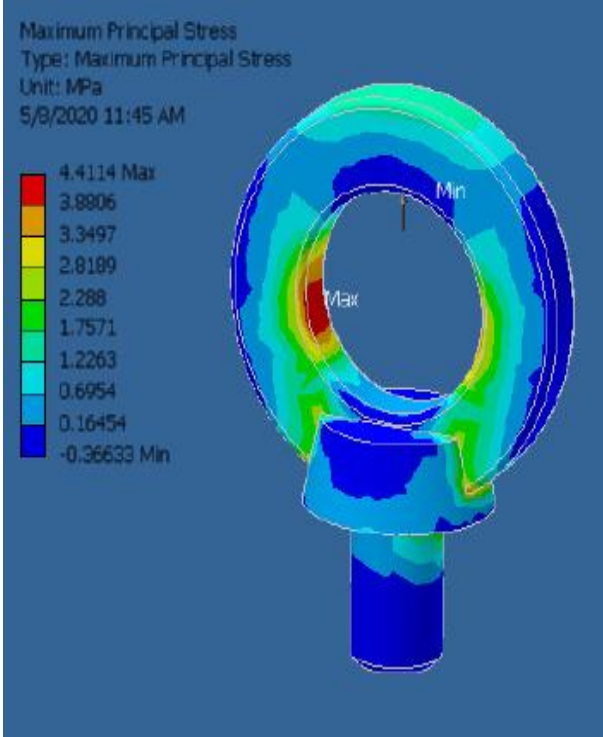

MAXIMUM PRINCIPAL STRESS

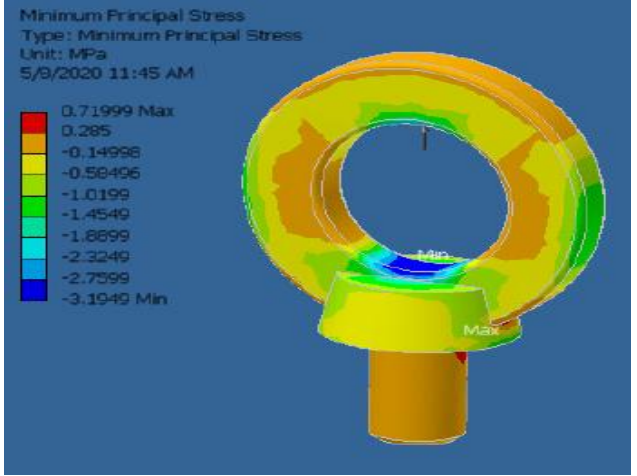

MINIMUM PRINCIPLE STRESS 
ISSN: 2277-3754

ISO 9001:2008 Certified

International Journal of Engineering and Innovative Technology (IJEIT)

Volume 10, Issue 3, September 2020

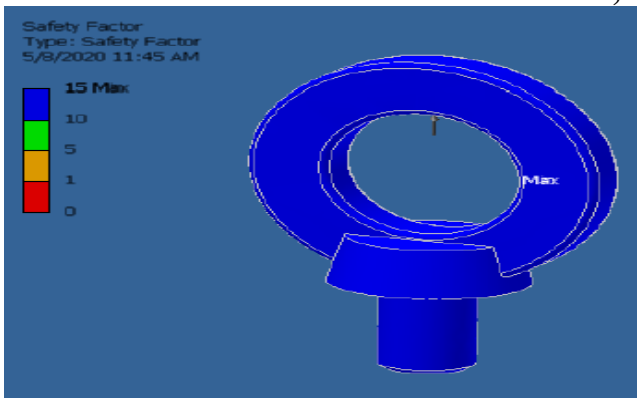

SAFETY FACTOR

Fig.13.Maximum Principle Stress, Minimum Principle Stress and Safety Factor of Rectangular cross section F. FEM Analysis of eye bolt having Trapezoidal Cross Section

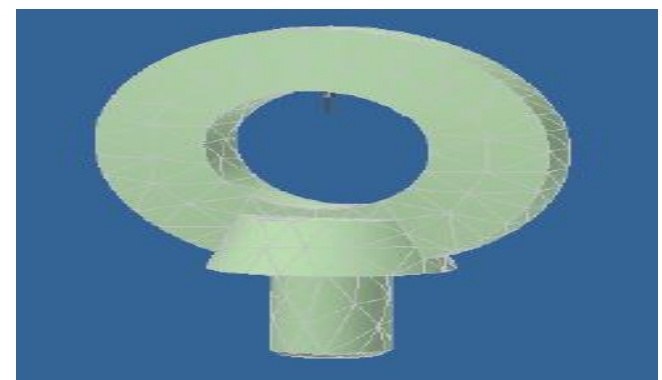

MESH MODEL

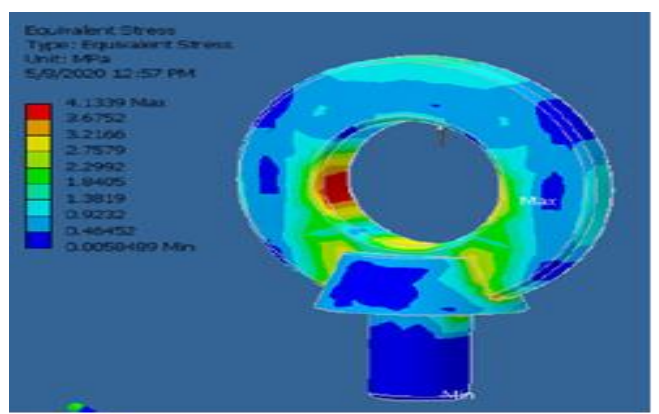

EQUIVALENT STRESS

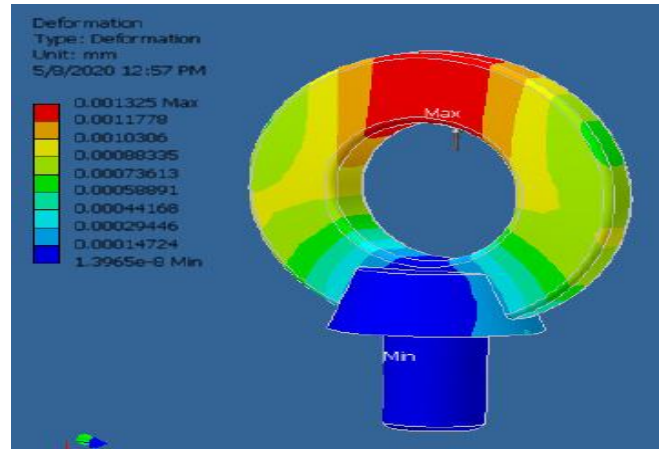

DEFORMATION

Fig.14. FEA analysis of Eye Bolt Having Trapezoidal Cross Section

Table 4. Induced Stress and Deformation Eye Bolt Hook Trapezoidal Cross Section

\begin{tabular}{|c|c|c|}
\hline & Maximum Value & Vinimum Value \\
\hline Equivalent Stress & $4.1339 \mathrm{~N}^{\mathrm{mm}} \mathrm{m}^{2}$ & $0.001325 \mathrm{Nmm}^{2}$ \\
\hline Deformation & $0.0058489 \mathrm{~mm}$ & \\
\hline
\end{tabular}

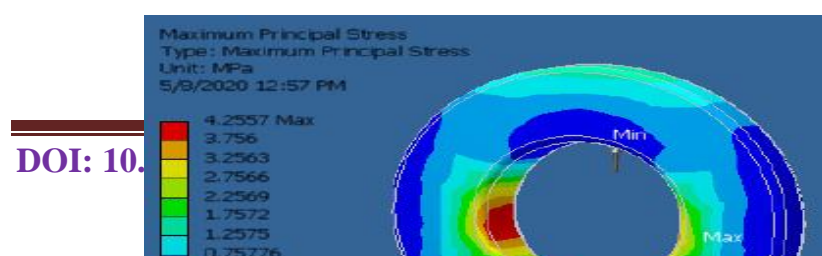

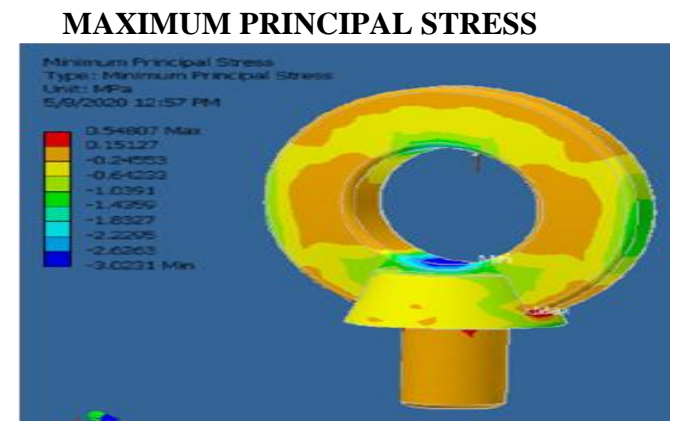

MINIMUM PRINCIPAL STRESS

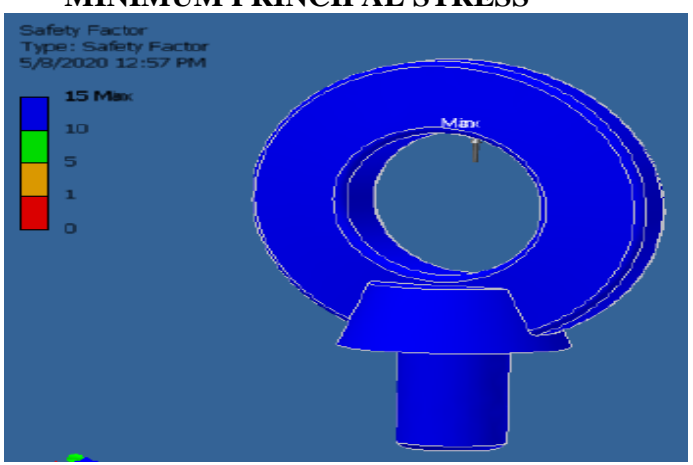

SAFETY FACTOR

Fig.15.Maximum Principle Stress, Minimum Principle Stress and Safety Factor Trapezoidal cross section

\section{CONCLUSION}

In design of crane hooks FEA tool can be effectively used. The FEM research is one of the most effective and efficient stress analysis approaches. From result it is observed that trapezoidal section have minimum stress and deformation level. Concluded that material having less deformation will have more stability and less failure. In this work optimization is carried out for geometry and concluded that trapezoid section have minimum stress and deformation Material selected is only high strength low alloy steel for different material also analysis can be carried and decide which material is most suitable for particular load condition.

\section{FUTURE WORK}

In this work optimization is carried out for geometry and concluded that trapezoid section has minimum stress and deformation. Material selected is only high strength low alloy steel. For different material also analysis can be carried and decide which material is most suitable for particular load condition.

\section{REFERENCES}


ISSN: 2277-3754

ISO 9001:2008 Certified

International Journal of Engineering and Innovative Technology (IJEIT)

Volume 10, Issue 3, September 2020

[1] Ajeet Bergaley and Anshuman Purohit"Structural Analysis of Crane Hook Using Finite Element" International Journal of Innovative Science and Modern Engineering (IJISME), Volume-1, Issue-10, pp: 3-7, September 2013.

[2] Santosh Sahu, Ritesh Dewangan, Manas Patnaik, Narendra Yadav, "Study of Crane Hook Having Trapezoidal Section by Finite Element Method \& Design of Experiments "International Journal of Modern Engineering Research (IJMER), Vol.2, Issue.4,pp-2779-2781, July-Aug 2012.

[3] A. Gopichand, R.V.S.Lakshmi, B. Mahesh Krishna," optimization of design Parameters for crane hook using Taguchi method" International Journal of Innovative Research in Science, Engineering and Technology, Vol. 2, Issue 12, pp: 7780-7784, December 2013.

[4] Chetan N. Benkar, Dr. N. A. Wankhade," Finite element stress analysis of crane hook with different cross sections "International Journal For Technological Research In Engineering Volume 1, Issue 9, pp:868-872, May-2014.

[5] ASME Standard B30.2, "Overhead Gantry Cranes (Top Running Bridge, Single or Multiple Girder, Top Running Trolley Hoist)," 2005.

[6] ASME Standard B30.9, "Slings Safety Standard for Cableways, Cranes, Derricks, Hoists, Hooks, Jacks and Slings," 2006. 